\title{
5 G Suspending the World: Romantic Irony and Idealist System
}

\author{
Kirill Chepurin
}

This paper revisits the rhetorics of system and irony in Fichte and Friedrich Schlegel in order to theorize the utopic operation and standpoint that, I argue, system and irony share. Both system and irony transport the speculative speaker to the impossible zero point preceding and suspending the construction of any binary terms or the world itself - an immanent nonplace (of the in-itself, nothingness, or chaos) that cannot be inscribed into the world's regime of comprehensibility and possibility. It is because the philosopher and the ironist articulate their speech immanently from this standpoint that system and irony are positioned as incomprehensible to those framed rhetorically as incapable of occupying it. This standpoint is philosophically important, I maintain, because it allows one to think how the (comprehensibility of the) world is constructed without being bound to the necessity of this construction or having to absolutize the way things are or can be.

KEYWORDs: irony, system, incomprehensibility, German idealism, German romanticism

At stake here is ... a way of actualizing without beginning with the possible.

\section{—Levinas, "The Temptation of Temptation"}

How is this world that we experience made comprehensible? In the Kantian framework inherited by Early Romanticism (and shared by Johann Gottlieb Fichte and Friedrich Schlegel, the two protagonists of this paper), to inquire into the comprehensibility of the world (of experience) is to 
inquire into its conditions of possibility. It is to ask: how is it possible to construct-and talk about - the world? When Schlegel wonders "is not this entire, unending world constructed by the understanding (Verstand) out of incomprehensibility (Unverständlichkeit) or chaos?" (KFSA 2:370), ${ }^{1}$ this question at once follows and subverts Romanticism's Kantian origin. In Kant, it is the incomprehensible in-itself-reality as it exists independently of, and prior to, our relation to it - that provides the subject with the material of sensation, which the understanding arranges into the world of experience with the help of the categories, such as one and many, reality and negation, or substance and accident. The standpoint of the in-itself, however, remains cognitively inaccessible to the subject; Kant famously prohibits any overstepping of the limits of the world constructed through the categories. This marks the categories themselves as necessary for the world to appear to the subject in the first place-for the world to be possible. The world can only be structured, and articulated, in this (categorial) way for it to cohere. The categories are thus fixed, and justified as necessary. They are also binaries or dichotomies that are then synthesized or mediated (e.g., oneness and plurality into totality, or reality and negation into limitation). We construct the world, and move through the world, as we arrange reality in binary terms. The logic of the world's articulation-and of its very possibility - is the logic of the binary, and the world is thereby constructed as, fundamentally, a world of division and opposition, which the understanding strives to synthesize into a coherent whole.

Schlegel, too, acknowledges that the world functions this way. We employ binary terms in order to construct the world or make it comprehensible-not just the ones found in Kant's table of categories, but many others, too: high and low, free and unfree, familiar and strange, serious and jocular, natural and artificial, beautiful and ugly. The speculative shift that Schlegel undertakes vis-à-vis this framework is, however, crucial. It consists, as I argue, in thinking immanently precisely the standpoint of "incomprehensibility or chaos" as the (impossible yet real) in-itself that precedes the world to be constructed and the very possibility of a world-a standpoint at which the familiar categories of the world, and the binary logic that underlies them, are completely refused or collapsed. To inhabit immanently this standpoint is, for Schlegel, the task of irony: "irony," he writes, "is the clear consciousness ... of an infinitely full chaos (des unendlich vollen Chaos)" (KFSA 2:263). The operation of irony, the way this paper rereads it, indexes the full collapse of all binaries at once, to the point of their chaotic indistinction, transporting the ironist to the standpoint 
prior to the world's construction, from which the ironic speech must be articulated as incomprehensible-as completely ungrounding the assumed comprehensibility of the world. At this standpoint, the categorial structure of the world and the process of constructing the world are collapsed, and the world is completely suspended. From the point of view of the world, this standpoint is absolutely incomprehensible, and absolutely impossible. And yet it is necessary for the ironist to think it, and to articulate her speech immanently from this standpoint, so as at once to think how the world is constructed and to reveal that incomprehensibility or chaos out of which it is constructed - an incomprehensibility that, as such, remains obscured or foreclosed if we simply take the way the world is constructed for granted or justify it as the way the world necessarily is or the only way it can be.

We may call this standpoint utopic, insofar as, preceding the world's construction, it is not located anywhere in the world: a nonplace outside of space, time, or the world's regime of reality, possibility, or comprehensibility more generally, which the ironist, however, must occupy, so as to suspend completely the construction of the world and to be capable of constructing-or deconstructing - any possible binary, and any possible world, immanently from this standpoint. In this, I suggest, the standpoint and operation of irony coincides with the standpoint and operation of the system in (non-Hegelian) German idealism, particularly in Fichte. The rhetoric of the system is, of course, ubiquitous in German idealism, with "the system" naming the standpoint from which all speculative speech-all philosophical construction and narrative-must be articulated. However, I want to push against the common image of the system as an inflated synthetic totality seeking to incorporate all that is singular or separate into itself-an image that itself assumes the primacy of separation and the logic of synthesis (as bringing what is separate into unity). Instead, I pursue an idealist trajectory in which the system marks a total displacement and suspension of the way the world is, and the way it is (endlessly) constructed, transporting the speculative philosopher to a standpoint that must be thought of as preceding the world's construction and refusing any "dogmatic" logic of the way the world is, defined in terms of binary oppositions, narrative, and the fixedness of things. This will allow me to bring system and irony together, rereading them together to reveal their shared starting operation (of the total suspension of the world) and the shared utopic standpoint established by that operation, from which they (and, accordingly, idealist and romantic critique) immanently proceed. 
Exegetically, this paper rearticulates the idealist concept of the system and, through it, the Romantic concept of irony. In contrast to the readings that position system and irony against each other, I focus not on their difference but on the standpoint and operation that, I argue, they share. In offering a reconfiguration of the system-irony conjunction, I do not, however, seek to resuscitate the terms "irony" or "system," or to argue in favor of a revival of Schlegelian irony or the idealist system. Nor is it my intention to intervene explicitly into the long-standing scholarly debate on Romantic irony. ${ }^{2}$ The stakes are for me, rather, philosophical and speculative. At issue is the very utopic operation and standpoint outlined above, which in this paper I theorize using the resources of German romanticism and idealism-so as to offer an account of a specifically "idealist" way of thinking a nonplace that refuses to be inscribed into the world's regime of comprehensibility and possibility, and from which the speculative speech (of the ironist or the speculative philosopher) must proceed. This standpoint, I argue, allows us at once to think the way the world is constructed and made comprehensible - and not to absolutize, dogmatically, the course of this construction or the way things are. Over the course of this paper, by rereading Fichte and Schlegel, I assemble this utopic standpoint, which suspends completely any dogmatic grammar of the world's articulation and construction, before offering additional remarks on this standpoint's philosophical importance.

\section{THE SYSTEM AGAINST THE WORLD}

To say that "the system" may serve, in German idealism, to mark a total suspension of the way the world is endlessly constructed, and a standpoint that completely precedes this construction and refuses fully any dogmatic logic of the way the world is, is to invoke an unusual kind of totality or completeness. What kind of totality is this? It must be different, for sure, from the (synthetic, mediated) totality of the world or the kind of total coherence toward which the understanding strives. Traditionally, totality is imagined to be something that combines everything into itself: an allencompassing, limitless synthesis. At the utopic standpoint that I seek to outline here, however, it is precisely that traditional kind of totality (the world as the sum total of everything that is or can be) that is refused. Here, the entire construction of the world is suspended, and no synthesis, no striving toward an all-encompassing unity, takes place. This kind of totality marks not merely a local interruption or partial subversion of the way the 
world is being constructed, but a complete suspension of the world, right now, opposing totally its endless construction.

On this point, the late Fichte is radically clear. For Fichte in the $18 \mathrm{r} 2$ Doctrine of Ethics, the world is never now. It is always not yet-not yet complete, not yet ethical - and always in transition toward a future. In Lecture 22, where he sums up some of his preceding argument, Fichte says,

[I said previously:] the morality of all as a complete system. The moral person must, therefore, want this system to be completed, and he knows that it must be completed. Still, he also knows, equally well, that it cannot be completed until every individual image appears, or emerges into the life that is collectively intuited, and is raised through all toward the unitary concept. Thus, he knows that this world, into whose series new individuals are continually entering in order to be formed ( $z u$ ibrer Bildung), this world of being born and passing away, must at one point (einmal) come to an end, and that a world must come into being in which the species, now a complete [or perfect] (vollendete) unity, is occupied with its proper task of actualizing (realisieren) the true image that has appeared; - the world for whose sake alone the present one is there, as the condition of its possibility. Moral consciousness is consciousness of the world in itself. The latter is the appearance of the absolute image. The presently given is not [the appearance of the absolute image], and cannot be. (Fichte 20I2, 357-58)

What is interesting in this passage is not so much the reference to a future world but the logic of the given world as well as its suspension that the moral person must undertake. In fact, the logic of the future is in this passage the logic of the world: the world as not-yet-ethical is here but a reproduction of the unethical, mobilizing the biological reproduction in its service. It is a promise of the ethical in the future that serves only to forestall it in the now via a serial reproduction of the same or "presently given"-which "cannot be" otherwise. The fundamental contradiction here consists in the fact that the presently given both "cannot" and "must" be otherwise. Fichte's way out of this contradiction involves, however, not any sort of synthesis or indefinite waiting for the future, but a full suspension of the world's ever-ongoing construction and the very logic of the not-yet-a suspension that also suspends the standard relation between "before" and "after." Since the world "cannot be" otherwise until it ceases to be the "presently given," 
it is therefore futile for the moral person to sit around and wait for the transcendent event of the end of the world-because that would mean succumbing to the logic of the world and doing exactly what the world would like the moral person to do in order to endlessly reproduce itself.

It is thus, for Fichte, impossible to be ethical in this world-impossible to be ethical now-without suspending the regimes of possibility and reproduction that structure the world, because as long as this reproduction continues, the now does not happen and the world prevents it from happening. The ethical conviction of moral consciousness appears, within the world with its not-yet, as "one point" in the future where the given world is supposed to come to an end; however, in order to be moral, it must be consciousness not of the given world but the "world in itself"-it must, in other words, complete and suspend, at once, the given world in order to proceed, immanently and now, from the standpoint of the in-itself.

This standpoint is one from which the moral person (and the speculative philosopher) immanently acts and speaks. Fichte's name for this alternative to the logic of the world is "the system" - an alternative that is endlessly deferred by the world, but names precisely the complete ethical viewpoint from which moral consciousness must proceed. Moral consciousness is moral insofar as it begins with the standpoint of systematic-ethical completion, serving to stop the world's cycle of the not-yet. This suspension is the act, method, or operation of the system. It is here completion or totality that suspends the endless progression or deferral perpetuated by the world, and with it, the binary logics of the not-yet and transcendent futurity, in order to begin, actively, from the commitment to the ethical. Fichte's "world in itself" points toward a way of articulating a total refusal of the ("presently given") world — or a way of beginning immanently with a utopic standpoint that fully suspends and precedes (as "the world in itself") the world as presently given.

Epistemologically and not just ethically, too, the system (of principles of knowledge) is for Fichte that which, from the standpoint of completion, suspends the world of things, or any dogmatic grammar of the real. Just to provide one possible example out of many, we can discern this logic in the 18II Doctrine of Science (Wissenschaftslebre), where Fichte explains the relation of the Doctrine of Science to the system of knowledge, as well as its opposition to dogmatism:

They [i.e., the dogmatists] think of things as the first (die Dinge als das erste), and make knowledge depend on those, be formed 
through those.-For them, knowledge is nothing independent (nichts selbstständiges), nothing to be recognized immediately, and does not define itself through itself.- $\{$ The dogmatist says:\} If you ask me: what is in knowledge?-Then I will point you to being (das Seyn): in the former there is [exactly] that which is in the latter. They [i.e., the dogmatists] cannot have any Doctrine of Science whatsoever; that would be [for them] the doctrine of nothing (das wäre die Lehre von nichts). Instead they have doctrines of things, ontology, cosmology, etc. Henceforth we [i.e., Fichte] give ourselves the task ... of thinking of knowledge as something independent - and for that matter, first, the question of whether things can still have any being outside knowledge if left in their place. As a result, instead of images of things, we obtain principles of knowledge. (Fichte 2003, 3-4)

I.) Knowledge structures itself through itself as an organized and articulated full system. 2.) One part of that system is its concept of itself in its above-mentioned original organization. This is, precisely, the W.L. [i.e., Wissenschaftslehre]. (Fichte 2003, I5)

Let us observe the rhetoric of nothingness in the quoted passage, and the way Fichte defines the starting point of the Doctrine of Science visà-vis dogmatism in explicitly utopic terms: critical philosophy questions the place of things, dis-placing the world of things by proceeding from that which, for the dogmatic philosopher, is literally nothing or nowhere ("das wäre die Lehre von nichts"). For the critical philosopher, however, this nowhere is the now-here from which the Doctrine of Science gets going as a matter of fact (Fichte often says that the Doctrine of Science proceeds from the premise that knowledge is a fact)-and which coincides with the original (non)place of the full system. Furthermore, the point from which the Doctrine of Science begins to be articulated, as part of the system of knowledge, and on which it reflects, is the point of the original completion of the system of knowledge as such-a point that must, therefore, be thought of as preceding the division into before and after, as well as part and whole. It is thus a total dis-placement of all dogmatic position, a full "interruption and cancellation" (Unterbrechung und Aufhebung, to use a phrase we will encounter in Schlegel), not of, but by the move of completion itself. The standpoint from which the critical philosopher articulates her speech is marked by the refusal of the dogmatist articulation (as proceeding from the point of view of the world as 
it is) - a refusal that transports the idealist from the standpoint of being (Seyn) to the standpoint of the nowhere or nothing.

\section{INTERLUDE: THE OUGHT AND THE CAN}

Before we proceed to Schlegel's rhetoric of irony, consider the irony of Fichte's moral consciousness: we cannot think the commitment to the ethical in the world without thinking, at the same time, a full suspension of the world, and vice versa. If moral consciousness were to think exclusively the in-itself, it would not be able to grasp or interrupt the logic of the world; and if moral consciousness were to proceed only from the given world, then, caught in the endless loop of the not-yet, it would not be able to be moral or articulate true morality - because morality, as we know already from Kant, proceeds from Sollen (ought), not Können (can):

Pure reason contains ... principles of the possibility of [moral] experience, namely of those actions in conformity with moral precepts which could be encountered in the history of humankind. For since they command that these actions ought to (sollen) happen, they must also be able to (können) happen. (Kant I9II, 524 $[\mathrm{A} 807 / \mathrm{B} 835])$

Or, in the early Fichte's seemingly less radical formulation:

We will find his [i.e., Spinoza's] highest unity again in the Doctrine of Science; though not as something that is, but as something that ought to, yet cannot, be produced through us (durch uns hervorgebracht werden soll, aber nicht kann). (Fichte 1965, 264)

The contexts here are different and would require further unpacking, but the common Kantian-Fichtean figure of Sollen versus Können is, importantly, a figure not of endless approximation but of the suspension of endless approximation. That is, because we cannot (reach full knowledge or morality from within the world), we need to suspend the Können and begin from the Sollen, which coincides with the utopic point of the system's completion. In Kant, this means beginning with the immanent commitment to the moral law, a commitment that reason enacts (and articulates), at every moment, as a matter of fact (as Faktum der Vernunft, the "fact" as well as "deed" of reason; Kant 1913, 31)—as evident, for example, in one 
of the formulations of the categorical imperative with its emphasis on jederzeit:

Act so the maxim of your will could hold every time (jederzeit) at once as a principle of universal legislation. (Kant 1913, 30 $)^{4}$

Our morality is not, for Kant, modeled after nature or our historical efforts to act morally. Instead, the moral law interrupts those to begin, at every moment, from its own ideal completeness. It is thus only by way of a radical insistence on the moral law's facticity that we can begin to conceive of something like a repetition of the operation of morality in the world, which must suspend the world so as not to be conditioned by it (and its regime of possibility and impossibility). The moral law is repeated across different moral subjects, and across every moment of the subject's agency, but it is always enacted as complete, fully ungrounding the plane of extra- or premoral experience. This means that moral consciousness must keep in mind, jederzeit, both what it can and what it ought to do, except without distinction between the two-collapsing both to the point of indistinguishability-so that there is not only a suspension of the can by the ought, but also a suspension of their standard order of succession and the very division between them. The now or at-once of the system serves to suspend "before" and "after" in order to begin with a utopic nowhere-with an ideality that must be understood as preceding this division before bifurcating, immanently, into it.

\section{THE CHAOS OF IRONY AND THE COLLAPSE OF THE WORLD}

What I would like to suggest, so as to continue assembling this standpoint of the utopic nowhere prior to the world's possibilities, is that Schlegelian irony operates in the same way, enacting a similar move of the complete suspension of the world - to the point of its de-creation, or reduction to a special kind of nothingness, which Schlegel alternatively terms "chaos" or "the neutral." This raises the stakes of this utopic standpoint even further, since it amounts here explicitly to a full collapse of all the binaries that serve to construct or articulate the world and its comprehensibility. Irony, as we know, is for Schlegel "the clear consciousness ... of an infinitely full chaos"a formulation that itself suspends the clear-chaotic binary, as well as the opposition between chaos and consciousness. Consciousness is, after all, the organ of the world's comprehensibility, involving the capacity to make clear 
distinctions. Chaos, however, indexes the collapse of all distinctions, in which consciousness would normally be understood to lose all sense of orientation and clarity. At the same time, chaos is also what precedes, and undoes, any well-formed or well-constructed world. Given his fascination with mythology, and his famous proclamation of the need for a "new mythology," Schlegel obviously has the mythological sense of chaos in mind, too: chaos as the anterior incomprehensibility which is prior to the cosmos and out of which the cosmos is formed.

To have a clear consciousness of the total chaos is to find oneself, impossibly, at the standpoint that at once precedes and suspends the distinctions or binaries that make up the world, and is not located anywhere in the world as the mind constructs it - a standpoint from which, however, the ironist (immanently and consciously) proceeds. The ironist is capable of taking any pair of binary terms on which the comprehensibility and constructability of the world is based, and subverting or collapsing themso that, faced with irony, the subject cannot know whether the ironic text or ironic speech is serious or jocular, where the higher might become the lower and the lower the higher, where the familiar might be revealed as strange, the natural as artfully constituted, and the ugly as beautiful. That is the case because the ironist can think the point of complete indistinction between any given terms, canceling out and reconfiguring their habitual meaning, hierarchy, and order of succession. It is only if all binaries are suspended at once that an "infinitely full" chaos can be immanently thought. Here, again, it is a totality (total disorder or chaos) that serves to cancel out the construction of the world and the logic of the binary on which it is premised-a totality that cannot itself be inscribed into the process of construction.

During his early Romantic period, Schlegel seems to be mesmerized by the chaotic excess of possibility opened up by, or from the standpoint of, the complete suspension enacted by the operation of irony, which he proceeds to regard as suspending all binaries at once-nature and art, lower and higher, etc., and even systematicity and nonsystematicity (KFSA 2:I73). The fact that the operation of the "all" for Schlegel collapses and suspends any binary, and must be thought of as preceding any binary, is further suggested by his articulation of, simultaneously, seriousness (Ernst) and jest (Scherz) asserted by irony:

In irony, all should be jest and all seriousness (In ibr soll alles Scherz und alles Ernst sein). (KFSA 2:160) 
As David Martyn observes, Schlegel does not mean to imply that "Scherz and Ernst are two components of irony"; rather, here, "one should not distinguish between Ernst and Scherz." However, I would disagree with Martyn's claim that this indistinction amounts simply to an "alternation" (Wechsel) between the two-so that everything is at one moment seriousness, at another moment jest (Martyn 2000, 80). The "all" suggests to me not an alternation, but an affirmation of a point of complete simultaneity and indistinction, in which the two (and any other opposing terms) coincide at any given moment. The temporality of chaos can only be an "at once" in which all binaries are suspended together, immediately and totally.

This kind of "all" or "at once" is generally indicative of what Schlegel means by the chaos of irony - a far cry from mere arbitrariness, indexing instead a totality that escapes and precedes the logic of the binary. There is, he notes, a special kind of "chaos" or "confusion" that is itself "properly constructed, with method and symmetry," in a move of "logical disorganization" (KFSA 2:403). This "symmetry," characteristic of chaos, obviously cannot be the standard symmetry in which A would be demarcated from and opposed to -A. In fact, "symmetry" names here precisely the structure of indistinction between any binary terms, or the total ("infinitely full") collapse of all dichotomies. In nature-philosophical and chemical terms, Schlegel speaks of this standpoint as "the point of absence of difference (Indifferenzpunkt) where everything is saturated" (KFSA 18:39r), where everything is, to the point of indistinction, dissolved into one. This is, as it were, irony's own ought: to inhabit (and articulate) immanently the utopic standpoint of absolute nondifference and indistinction.

Chaos, as naming the totality enacted by irony's operation of complete suspension, is the zero point or the in-itself preceding the world and collapsing its divisions. And yet, in the same stroke, it may also be seen as containing, in a chaotic, unformed state, the material out of which any binary, and thus the world as a whole or any possible world, can be freely constructed. Just as we saw the moral consciousness in Kant and Fichte having to keep in mind, jederzeit, the way the world is and the way the world ought to be, inverting their standard order of succession and suspending the world via the ought-so the ironist, too, at once keeps the construction of the world in mind and collapses the distinctions on which this construction hinges. The ironist must, in other words, be cognizant at once of the chaos and of the way the world is or can be constructed from the chaos-suspending this meta-opposition, too. Chaos is that in which there is no world, a nonworld, no-thing, a nothing; but it is also that out of which 
a world can be made to emerge: "only that confusion is a chaos which can give rise to a new world" (KFSA 2:263).

In a particularly dense fragment from his philosophical notebooks, Schlegel brings together chaos, nothingness, and the world in the following way:

The chaos relates to the nothing in the same way that the world relates to the chaos. Chaos [is] the only real concept of the nothing. Nothingness itself [is] a purely analytic concept. . . . The neutral, too, is confusion and chaos.... Nothing is more original than the chaos (Nichts ist origineller als das Chaos). (KFSA 18:78) $)^{5}$

To speak of nothingness, this purely ideal or "analytic" absence of anything, is to speak, in reality, of chaos understood as a state in which all oppositions have been dissolved or neutralized toward the all-encompassing Indifferenzpunkt-or, looking at this from the hypothetical position of a world to be created, a state where oppositions are only to be constructed. In this way, the world is fully disorganized, reduced affirmatively to a null point where "everything is saturated," without difference. There is, in this chaos, no trajectory or topos, no movement of mediation or distribution of possibility and actuality. Chaos is nothingness considered to be productive and generative, or real ("the only real concept of the nothing") - an immanent materiality of nothingness, the world de-formed. It is the void of absolute indistinction grasped, so to speak, as pure material in which all distinction is collapsed and from which the work of construction (of a world) immanently proceeds. Irony is an apocalyptic operation marking a complete breakdown of the conceptual apparatus that upholds the worldan operation of total disorder.

As the operation of "confusion and chaos," irony (dis)places us before the creation of any of the world's categories or dichotomies, completely ungrounding the world as given. Chaos is first, not merely as the beginning or origin (of a process of construction), but as a persistent ante-archic force, which the ironist uses, jederzeit, to suspend all construction. Each time the ironist acts out of the impossible nonplace of nothingness or chaos, she does not contain it or merely transform it into a world. She allows it to persist, exposing its primacy-revealing it to be prior to the logic of the world and its construction. In theological terms, the ironist is transported (as if) before creation, but without being bound to creation-without having to create any specific world or to justify the way the world is, without 
having to say "this is the only way the world can be." At this standpoint preceding the world, the ironist's u-topia coincides with that of the idealist philosopher: as noted by Schlegel, Fichtean idealism itself proceeds "as if from nothing" (wie aus Nichts) (KFSA 2:314). This amounts, in a way, to a peculiar transformation of the God's-eye view after the death of Godinto an aworldly standpoint of full suspension.

Schlegel's conception of irony as chaos is, to borrow Fichte's expression, a "doctrine of nothing," too, meant similarly to confuse the dogmatist. The philosophical basis of the confusion that the ironic speech causes in the reader or listener consists precisely in its affirmative reduction of all of the understanding's categories to pure chaos or nothingness. This confusion or chaos is what allows the ironist to articulate her speech as incomprehensible, as ungrounding totally any dogmatic comprehensibility of the world. As a result, to someone who does not "have irony," as Schlegel puts it, ironic speech-and the standpoint of chaos that the ironist impossibly articulates- "remains a mystery" or means nothing at all (KFSA 2:I60). In Schlegel's On Incomprehensibility, this is the general public-the confused reader of the Romantic journal Athenaeum, to whom the standpoint of irony is too alien, too divorced from common sense (der gesunde Menschenverstand, literally "the healthy human understanding"; KFSA 2:362). The figures of the dogmatist in Fichte and the commonsensical public in Schlegel serve equally the purpose of decoupling system and irony radically from the perspective of the world - and yet the point of irony is not to be unhealthy or incomprehensible for its own sake, and not merely to provoke the public, but to undo these binaries themselves and their logic. The reader or listener has to go through the highest incomprehension to reach a point at which the commonsensical duality of "comprehension" and "incomprehension," too, is canceled out (KFSA 2:367; cf. 362), along with any supposed stability of the world and its construction.

\section{A PERMANENT DIGRESSION (FROM THE WORLD)}

The chaos of irony serves to suspend the flow of any construction in which we are habitually engaged, of which the construction of the world by the understanding is the central philosophical example. It can be a literary construction too. In a different, aesthetic-rhetorical register, the same operation is at work in Schlegel's well-known description of irony in terms of parekbasis (a rhetorical term meaning digression) as well as what, in Ancient Greek comedy, was called parabasis (a "stepping forward"), a digression 
in the middle of the play during which the chorus moved closer to the audience to address it directly in the author's name, delivering commentary on the play as a whole, the authorial intentions, and any contemporary figures and events.

Parekbasis is how Friedrich Schlegel characterizes irony: "Irony is a permanent parekbasis (Parekbase)" (KFSA I8:668)—and parabasis is the prime literary example he uses to illustrate it, starting already from his 1797 handwritten notes on ancient poetry (Benne 2015, 432-33), to the point of often using the two terms interchangeably (e.g., KFSA 5:222, 5:25I). In his later lectures on the history of European literature, he describes parekbasis/ parabasis thus:

[It is] a speech that in the middle of the play is addressed by the chorus to the people in the name of the poet. Yes, it was a total interruption and cancellation (gänzliche Unterbrechung und Aufhebung) of the play, in which ... the greatest licentiousness (Zügellosigkeit) reigned and in which the rudest things were said to the people by the chorus that was stepping out to the very edge of the forestage. It derives its name from this stepping out (ékbasis). (KFSA ir:88)

Cf. "Parekbasis and chorus are necessary for every novel (as potency).” (KFSA i6:265)

It has become habitual to read parekbasis in Schlegel as a rupture in the whole, and irony therefore as either a limiting technique or, on the contrary, a technique of transcendent excess. True, parekbasis serves to "disrupt" or suspend "the movement of a straight line" or any "sequential unfolding" of the whole (Newmark 1992, 907-8)-to interrupt the construction of a linear narrative (be it the world or the play). This is, however, still too limited of a perspective on parekbasis/parabasis (and on Schlegelian irony as the permanent, total parekbasis). For Schlegel, the narrative of the play is precisely not the whole - or a very limited whole at most. It is, rather, the cancellation that is here total or whole (gänzlich). How does, after all, this "total interruption and cancellation" function? It proceeds by way of a stepping out from the play, transporting us to a chaotic standpoint from which the chorus articulates their speech. Not only does this speech, and this standpoint, reveal the constructed character of the play and its narrativetogether with the constructed nature of the entire scenic setup, including the division between the audience and the performers or the performers 
and the author. It also, in the same move, completely suspends not just the construction of the play or the divisions that make up the scenic situation, but all the lines of division or opposition at once: between the people, the performers, and the author; between the stage and the audience (hence the chorus's stepping out to "the very edge of the forestage"); between higher and lower; or between the play and the wider reality of the world (hence the commentary on contemporary events) - exposing these divisions as secondary and illusionary.

This total cancellation does not therefore merely create a digression from, or an opening in, the play's narrative. It also lets the world, as it were, immediately flow into the play through that opening so as to collapse, in this moment (in this now), all the divisions that serve to construct the entire situation - the entire world (of the polis) —of which the play is a part. This is what a Schlegelian reading of the parabasis in Aristophanes's The Clouds could look like-a scene that touches on the author's vision for the play (as something already complete), his career and standing as a playwright, and the city's political events, among other things, as well as includes prayers to the gods and the invitation for them to join the chorus in its dance, right now. What may be seen as emerging here is, as it were, the ultimate now, a viewpoint from which to consider not only the play as something complete, but the now of the author, the society at large, the gods in their eternal now, the chorus, and the audience (united with the chorus via both physical proximity and the obscenities and anecdotes). One could say that, in this, parabasis proceeds from the now as something complete, from a complete or extended now that complicates and suspends the part-whole relation, as well as, in a perfectly critical-philosophical fashion, any dogmatic givenness - of the play, but also of the world. The "breaking of the illusion" (KFSA rr:88) here goes both ways, impossibly suspending, on the stage, the world in the now.

By characterizing irony as the permanent, total cancellation or digression, Schlegel radicalizes this suspension by thinking of it not as secondary to the unfolding of the narrative- not merely as a scene that would interrupt a given construction (of the play or the world) - but as that which exposes the chaos and nonnarrativity foreclosed by the process of construction. At this standpoint, the logic of linear succession and the divisions that uphold it are collapsed. This, too, is a way of revealing the now or at-once of total suspension as primary vis-à-vis construction and as completely ungrounding the narrative as given. Irony as the permanent parekbasis/ parabasis acts thus as a suspension of "before" and "after," as well as a sort 
of summing up in the extended now. To say that irony is the "permanent parekbasis" is to insist on the total and persistent character of the suspension undertaken by irony, which does not just happen at one moment during the construction, but is nothing but this full suspension, before any particular construction can unfold as well as at every moment of this construction: the ironic jederzeit. The ironist, in other words, proceeds permanently from the now or nonplace of what suspends completely the logic of construction.

\section{FROM REVOLUTION (BACK) TO CREATION}

Despite Schlegel's historical association of irony with comedy or, in a different context, with the figure of Socrates (e.g., KFSA 2:160), the affirmative reduction to chaos at work in irony-to an impossible yet real standpoint of the full suspension of the world, from which all possible construction must be seen as proceeding - is for Schlegel, at the same time, the central task of the contemporary epoch. In fact, the logic of the complete suspension of the world, in the now, and its total de-creation toward chaos or nothingness is configured by Schlegel explicitly as a revolutionary logic-after all, the first operation of the revolution is also that of total disorder. Ironic speech is, for Schlegel, revolutionary speech, because it destroys the stability and fixedness of the accepted order of things that is the world, erasing it to the zero point of chaos:

The chaos that, in the modern world, has previously been unconscious and passive, must return actively; eternal revolution. (KFSA i8:254)

The essence of the modern [epoch] consists in creation from nothing. This principle ... can be found in the [French] Revolution, in Fichte's philosophy—and also in the new [romantic] poetry. $(\mathrm{KFSA} \text { 18:315 })^{6}$

According to the fragment from the philosophical notebooks quoted earlier, this creation from nothing is "really" indistinguishable from creation from chaos-which also indexes the coincidence of romantic critique and romantic art. Critique is for Schlegel itself an enactment, not of the logic of the world, but of the logic of chaos:

In critique everything coincides; history and philology, archaeology_-poetry and philosophy_and even encyclopedia; critique is 
the universal chaos (das allgemeine Chaos). Critique is universal art (universelle Kunst). (KFSA r8:366)

No wonder, then, that the same goes for the concepts of the romantic novel ("In its form, the novel is a well-formed artificial chaos"; KFSA 16:207) and romantic poetry ("Romantic poetry is related through and through to chaos and mythology"; KFSA I8:337). Creation from nothing or chaos becomes in Schlegel the universal critical method, as well as the method of all art: "the contact between the artist and the material is only thinkable as creation from nothing" (KFSA I8:I33). Similarly-seeing as the same (revolutionary) method is at work in Fichtean philosophy-"one cannot understand the Wissenschaftslehre without a sense for chaos" (KFSA 18:38). To say "nothing, or chaos" is, among other things, to complicate any clear distinction between ideal and material, as well as analytic and synthetic, in an act that must be thought of as preceding all narrative articulation or poiesis. Both romantic art and the Wissenschaftslehre, having to do as they are with refusing the "dogmatic" givenness of the world, have the same underlying (revolutionary) operation and the same underlying sense (for chaos). Starting from this chaos, and persisting at and with the standpoint of chaos as the material immanence that continues to lie below all construction, the ironist proceeds critically to construct any particular discursive terms (as well as any particular genres). ${ }^{7}$

This is not to say that chaos is only there at the beginning, but gets left behind as we proceed to construct the world. On the contrary, all further creation proceeds unceasingly from chaos in the process of "eternal revolution." We do not begin with the standpoint of irony in order to go back to the world, to its regime of possibility and reproduction. At stake is not merely a transformation of the world, or transition from old to new-at stake is a different logic of totality, in which we fully suspend the world in order to engage, in the now, in an immanent construction from this nowhere. In fact, there is nothing that, in Schlegel's utopian project of a total rearticulation of the world, could not be constructed within this unceasing revolutionary now, expanding into "the idea of the encyclopedia" as combining "philosophy and philology [with] poetry" (KFSA i8:364).

The rhetoric of the encyclopedia indexes Schlegel's ambition to create, from this standpoint, a radically different totality, a totality of all-dissolution as all-construction ("the encyclopedia contains finally the dissolution of philosophy in poetry"; KFSA I9:77), without distinction between past (as reconstructed for Schlegel by philology and history) and future (as constructed 
by romantic poetry). Schlegel's idea of poetry as "progressive" (e.g., KFSA 5:I93) reconfigures the idea of endless construction by decoupling it from a transcendent future (and thus from the structure of the not-yet) and tying it instead to the temporality of the immanent now as the utopic point at which past and future coincide, immediately and totally. One striking example of this indistinction is Schlegel's concept of prophecy or divination, paradoxically directed simultaneously toward past and future from within the now, since both are part of one process of construction-so that "the historian is a prophet turned backward" (KFSA 2:I76) and, on the other hand, "romantic poetry" can be characterized only by "a divinatory criticism" (KFSA 2:I83). Past and future coincide for Schlegel in, and can be produced or rearticulated only from, the now or the at-once. This, too, is inherent in the ironist's ought: a total reconfiguration and rearticulation of the world-which, like the moral ought in Fichte, becomes visible only at the utopic standpoint of complete suspension.

\section{“THE NOTHINGNESS OF ALL THAT IS OBJECTIVE”}

The utopic and revolutionary standpoint of chaos or nothingness serves therefore a twofold goal. On the one hand, it allows the ironist to suspend entirely the world's construction and all the binaries and divisions that it involves, exposing the ante-original incomprehensibility at the heart of the assumed comprehensibility of the world. On the other, the ironist does not simply remain at this standpoint. Now that she knows how all construction works, she can immanently construct a world or reconstruct the world from this standpoint in a critical-poetic process of creation that spans equally into past and future. What needs to be thought, in other words, is simultaneously the deconstruction of the world (to chaos or nothing) and its construction-one that is "artistic" or "poetic" in the sense of experimenting immanently with the pure material and constructing a world out of it: a construction decoupled from justifying the world under construction as simply (dogmatically) given, or as being necessarily the way it is. It is this decoupling that the terms "poetry" and "art" index. The ironist undermines any world she constructs by keeping open the capacity to confuse, to collapse any binary. The point is to think the way the world is constructed without investment in the way it is.

The same twofold goal is at work in Fichte, even if the purpose of the world construction is for him different. Fichte does not seek to repoeticize the world or to play around with all possible binaries, rearranging the material of the world poetically into a new world or new mythology. What he 
wants is to glimpse the ought that the world continually defers and prevents from being enacted ${ }^{8}$ - the ought foreclosed by the dogmatist's investment in the way the world is endlessly constructed and in the way things are. For the ought behind the construction to be glimpsed, however, the world as it is needs to be totally suspended or displaced. Otherwise, to leave the world in place would amount to thinking the can (the way the world is and can be) as prior to the ought, and thus to foreclose the ought by the can, transposing it into a transcendent future. For Fichte, the world, as we recall, at once cannot and ought to be otherwise. To say that the world can be only the way it is, is to condition the ought by the can and cannot, thereby precluding it. As a result, the structure of the operation of total suspension in Fichte coincides with that of Schlegelian irony. As we have seen in the case of moral consciousness, the idealist (not unlike the ironist) needs at once to keep in view the construction of the world—and to proceed immanently from the in-itself that, as such, suspends the process of construction and the world's regime of possibility and impossibility (i.e., its can and cannot). The objective way the world is, the movement of the endless unfolding and reproduction of the world, must be suspended so as not to absolutize dogmatically the world or the possibilities it is thought to provide.

That should not be taken to mean that the ironist or the speculative philosopher does not take seriously the objective movement of the world-the objective way things are or can be. For both, the fact that we tend to take the logic of the world and the (objective) way it is being constructed for granted is precisely the problem. A contrast with Hegel's rhetoric of objectivity and seriousness may prove instructive here. What Hegel criticizes about Schlegelian irony is that "irony takes nothing seriously" (I971, I8:460) and asserts "the nothingness of all that is objective" (1971, I3:96) — that it does not take the objective way in which the world has been historically constructed seriously enough. That is also his criticism of what he takes to be Fichtean subjectivism. Instead, Hegel's injunction is to take the world seriously and not to interrupt the movement of the world. A characteristic example of this can be found in his lectures on the philosophy of spirit, where he speaks of the objective "great whole, the self-accomplishing work of the world," which one can only (subjectively) embrace and participate in, but with which one may never interfere $(1994,55)$. Philosophy traces, for Hegel, the objective, lawful movement of spirit in and as the world. At each moment of history, spirit produces its own conditions of possibility as necessary for its actualization and forward movement, and the trajectory of this production is necessary, serving to legitimate the way the world is. No ought or in-itself 
that would completely suspend the world and its process of construction, disclosing what the self-accomplishing movement of the world would foreclose, is for Hegel thinkable or required. Hegelian morality (Sittlichkeit), too, is morality as objectively historically formed - one that proceeds from the worldly can and not from the utopic moral ought.

To destabilize the world's construction the way Schlegel does is, for Hegel, to endanger the teleology of spirit. Hegel's rhetoric of objectivity and seriousness is a theodicy, a mode of justification - of justifying the world and its regime of possibility. For Schlegel, by contrast, it is the seriousness of the world that is the problem. "The world," he notes, "is much too serious; seriousness is nevertheless rare enough" (KFSA 2:245). Given the apocalyptic character of irony as an all-encompassing suspension of the world, irony is no laughing matter, and is not just played for laughs. "Irony," Schlegel asserts, "is not to be joked with" (mit der Ironie ist durchaus nicht $z u$ scherzen; KFSA 2:370). Its seriousness is, however, antagonistic toward the seriousness of the world. The nonworldly standpoint of total suspension, as enacted by Schlegelian irony or the Fichtean system, is a threat to the world's seriousness because it refuses to identify the ought with the world's regime of possibility or construction-while also making it possible to think the way the world is being constructed, except without the (Hegelian) investment in the way it objectively is.

\section{CONCLUSION}

With this standpoint, we can think a "no" to the world and to the givenness of its construction, which at the same time discloses a chaotic in-itself and a utopic ought that precede the world and yet from which all construction-of the world or any new world-must be articulated. In this, the operation and standpoint of the total suspension of the world speak to some of the central concerns in contemporary thought. As Frédéric Neyrat has put it, one necessary theoretical task today is to think a "no" to the world, and to the allure of the possibilities the world is thought to provide, that would at the same time retain the "chaotic imagination that generates the promises of new worlds" (20I4). Referencing Keats, Neyrat calls this "no" a "negative capability." Attempts to think such a negative capability cut across the entire spectrum of contemporary thought. ${ }^{9}$ A key point of contention in the contemporary debate is precisely whether it is possible, or even desirable, to think the kind of "no" to the world - to this world (of Western modernity) that we have inherited and to the way it has been constructed—out of which 
a new world or a different future could be articulated. To some, "the whole possibility of and desire for a world" is pathogenic (Sexton 20II, 3I), and must be rejected so as to think immanently the chaos or confusion of the "no" itself as an atopic (non)position that cannot be inscribed into the distribution of possible positions that is the world. To others, however, the same atopic "no" or nonplace is to be thought in order to construct "other ways of being in the world, and ultimately new worlds" (Muñoz 2009, I). This latter type of thinking in particular marks a utopic strand within contemporary theory, and signifies a return to the archives of Early Romanticism-which now need to be thought anew. No wonder, in this regard, that Neyrat's call for imagining (chaotically) the utopic negative capacity turns to a Romantic poet and the Romantic chaos-world conjunction. ${ }^{10}$ This imagination must be chaotic, we could say, in order to be able to reduce the world affirmatively to chaos or the pure material, and to reconfigure it immanently. To think the possibility of new worlds, after all, one needs to think both the way the construction of a world proceeds and a refusal of the way the world is-co-articulated from a standpoint that would suspend completely their dogmatic order of succession, as well as the construction itself, so as not to be conditioned by or inscribed into it and its regime of possibility. The utopic standpoint preceding the world's construction that this paper has assembled may therefore be seen as an intervention into this ongoing return.

\author{
School of Philosophy \\ National Research University \\ Higher School of Economics, Moscow
}

\title{
NOTES
}

Research for this article was supported by the Academic Fund Program at the National Research University Higher School of Economics (grant I9-OI-045, 20I9-20) and by the Russian Academic Excellence Project “5-זoo." I would like to thank Joseph Albernaz, Alex Dubilet, Kyra Sutton, Daniel Whistler, the participants of Niklaus Largier's colloquium at UC Berkeley, and the journal's two anonymous referees for their comments on earlier versions of the text.

I. References are to the so-called Kritische Friedrich-Schlegel-Ausgabe (KFSA) (Schlegel 1958-), followed by volume and page number. Translations are mine.

2. At the same time, if I were to identify a tradition of scholarship that could serve as a starting point for my reading of irony, it would be the one running from Walter Benjamin, via Maurice Blanchot, to Philippe Lacoue-Labarthe and Jean-Luc Nancy. 
Particularly in Benjamin's nonsubjectivist reading of irony as "assimilation of the limited work to the absolute," Blanchot's description of the Romantic writing as a nontransitive, autorevelatory force, and Lacoue-Labarthe and Nancy's speculative identification of system and fragment, one sees the move beyond the traditional framework of Romantic subjectivity. See Benjamin 1996; Blanchot 1993; Lacoue-Labarthe and Nancy 1988.

3. English translation slightly modified from Fichte 2015, I22, additional emphasis mine.

4. Cf. the moral agent as fully "certain on the spot what he ought to do" (Kant I923, 287 ), without relation to, or in a way prior to, any external circumstances.

5. "Neutrality" is important here, insofar as the neutral indexes a refusal of the logic of the binary—a refusal that is "evidently neither negative nor dialectical" (Derrida 1986, 70).

6. In On Incomprehensibility, Schlegel also articulates the revolutionary origin of Fichtean idealism, itself "the great revolution" inaugurating the "critical epoch," to the point of calling the French Revolution "an allegory of the system of transcendental idealism" (KFSA 2:366). I would argue that the use of the term "allegory" is not accidental here. As a way of speaking in which different terms coincide, or are spoken about in and as one, allegory may also be regarded as a mechanism of indistinction, and thus of irony, "confusion," and chaos.

7. Cf. Hamacher 1997, esp. 200-20I, on the point where any transcendence of the genre stops (or becomes one with the condition of possibility of any or every genre).

8. On the need to glimpse the ought behind the world, see additionally Fichte 2000 , I79-96, a text that I analyze in Chepurin forthcoming.

9. Among the many possible examples-across such disparate fields as black studies, queer theory, and political theology—see Edelman 2004; Muñoz 2009; Sexton 20II; Sexton and Barber 2017.

Io. Significantly, the chaos-world conjunction is central to the less utopian and more "pessimistic" trajectory of contemporary thought too. Thus, Jared Sexton quotes Neyrat on the "chaotic imagination" and speaks of the "confusion" characteristic of the way blackness collapses the logic of the binary (Sexton and Barber 20I7). Daniel Colucciello Barber likewise aims to think "creation [as] immanent with the negativity of the non" and with "the No of chaos" (2016, 7-8).

\section{WORKS CITED}

Barber, Daniel Colucciello. 2016. "The Creation of Non-Being." Rbizomes 29: I-59. doi:10.20415/rhiz/o29.ero.

Benjamin, Walter. 1996. "The Concept of Criticism in German Romanticism." In Selected Writings, Vol. I: 19r3-1926, ed. Marcus Bullock and Michael W. Jennings, II6200. Cambridge, MA: Harvard University Press.

Benne, Christian. 2015. Die Erfindung des Manuskripts. Berlin: Suhrkamp.

Blanchot, Maurice. 1993. "The Athenaeum." In The Infinite Conversation, trans. Susan Hanson, 35I-59. Minneapolis: University of Minnesota Press.

Chepurin, Kirill. Forthcoming. "Knot of the World: German Idealism between Annihilation and Construction." In Notbing Absolute: German Idealism and the 
Question of Political Theology, ed. Kirill Chepurin and Alex Dubilet. New York: Fordham University Press.

Derrida, Jacques. 1986. Parages. Paris: Galilée.

Edelman, Lee. 2004. No Future: Queer Theory and the Death Drive. Durham, NC: Duke University Press.

Fichte, Johann Gottlieb. 1965. Gesamtausgabe der Bayerischen Akademie der Wissenschaften. Bd. I/2. Stuttgart-Bad Cannstatt: frommann-holzboog.

- 2000. Die späten wissenschaftlichen Vorlesungen. Bd. I. Stuttgart-Bad Cannstatt: frommann-holzboog.

- 2003. Die späten wissenschaftlichen Vorlesungen. Bd. II. Stuttgart-Bad Cannstatt: frommann-holzboog.

- 20I2. Die späten wissenschaftlichen Vorlesungen. Bd. III. Stuttgart-Bad Cannstatt: frommann-holzboog.

- 2015. Lectures on the Theory of Ethics. Trans. Benjamin D. Crowe. Albany: State University of New York Press.

Hamacher, Werner. 1997. "Der ausgesetzte Satz. Friedrich Schlegels poetologische Umsetzung von Fichtes absolutem Grundsatz." In Entferntes Verstehen. Studien zu Philosophie und Literatur von Kant bis Celan, 195-234. Berlin: Suhrkamp.

Hegel, Georg Wilhelm Friedrich. 1969. Science of Logic. Trans. A. V. Miller. New York: Humanities Press.

- 1971. Werke in 20 Bänden. Berlin: Suhrkamp.

- I994. Vorlesungen über die Philosophie des Geistes, Berlin I827/28. Hamburg: Felix Meiner Verlag.

Kant, Immanuel. I9II. Gesammelte Schriften. Bd. 3. Berlin: Georg Reimer.

- I913. Gesammelte Schriften. Bd. 5. Berlin: Georg Reimer.

- 1923. Gesammelte Schriften. Bd. 8. Berlin: Walter de Gruyter.

Lacoue-Labarthe, Philippe, and Jean-Luc Nancy. 1988. The Literary Absolute. Trans. Philip Barnard and Cheryl Lester. Albany: State University of New York Press.

Levinas, Emmanuel. 1990. Nine Talmudic Readings. Trans. Annette Aronowicz. Bloomington: Indiana University Press.

Martyn, David. 200o. "Fichtes romantischer Ernst." In Sprachen der Ironie-Sprachen des Ernstes, ed. Karl Heinz Bohrer, 76-9o. Berlin: Suhrkamp.

Muñoz, José Esteban. 2009. Cruising Utopia: The Then and There of Queer Futurity. New York: New York University Press.

Newmark, Kevin. 1992. "L'absolu littéraire: Friedrich Schlegel and the Myth of Irony." MLN I07 (5): 905-30.

Neyrat,Frédéric.20I4."OnthePoliticalUnconscious oftheAnthropocene."Societyand Space,20 Mar. https://www.societyandspace.org/articles/on-the-political-unconsciousof-the-anthropocene.

Schlegel, Friedrich. 1958-. Kritische Ausgabe seiner Werke. Paderborn-München-Wien: Verlag Ferdinand Schöningh.

Sexton, Jared. 20Ir. "The Social Life of Social Death: On Afro-Pessimism and Black Optimism." InTensions 5: I-47.

Sexton, Jared, and Daniel Colucciello Barber. 20I7. "On Black Negativity, or the Affirmation of Nothing." Society and Space, I8 Sept. https://www.societyandspace.org/articles/on-black-negativity-or-the-affirmation-of-nothing. 